\title{
Integrovaná terénní výuka jako systém
}

\section{Fieldwork and integrated education as a system}

\author{
Eduard Hofmann, Marek Trávníček, Petr Soják
}

\begin{abstract}
Anotace: Text se zabývá problematikou terénní a integrované výuky. Seznamuje nás s popisem různých forem terénní výuky na $\mathrm{PdF}$ MU s cílem najít společné prvky napříč spektrem jednotlivých dílčích kurzů, dále upozornit na možnosti kvalitnějšího uchopení takových forem a uspořádání do uceleného systému. Děje se tak u terénní výuky kateder geografie, tělesné výchovy a sociální pedagogiky. Dále se v textu prezentují výstupy z dotazníkového šetření a strukturovaných rozhovorů z padesáti základních škol v ČR, kde bylo sledováno, jak je vnímána potřebnost zavedení terénní integrované výuky do ZŠS.
\end{abstract}

Klíčová slova: terénní výuka, integrovaná výuka, pedagogika a volný čas, dotazníkové šetření, rozhovor

\begin{abstract}
The article deals with the fieldwork and integrated education. It introduces the results of the analysis of various forms of the fieldwork and integrated education at Masaryk University, the Faculty of Education, and the results of questionnaire survey and structured interviews at fifty schools in the Czech Republic. The aim of this analysis is to specify common factors of fieldwork education at the department of geography, physical education and social pedagogy. The goal of the questionnaire survey is to determine the current situation in the fieldwork education from the point of view of the integrated curriculum.
\end{abstract}

Keywords: field work, integrated learning education and leisure time study, questionnaire examination, interviews

\section{1 Úvod}

Současná kurikulární reforma staví učitele českých základních škol do nové situace. Jednou z priorit je důsledné využívání mezipředmětových vazeb a integrace jednotlivých předmětů. Obsah jednotlivých předmětů se stává prostředkem pro utváření základních cílů vzdělávání a formování jednotlivých kompetencí. K tomuto účelu přispívají především aktivizující formy a metody výuky, mezi něž patři nesporně různé formy terénní výuky. Před přečtením příspěvku si položme následující otázky: Co si představujeme pod pojmem „terénní výuka"? Co si predstavujeme pod pojmem , integrovaná výuka“? Jak oba pojmy spolu souvisejí?

\section{Přehled poznatků}

\subsection{Základní pojmy}

Terénní výuka je komplexní výuková forma, která v sobě zahrnuje progresivní vyučovací metody (pozorování, pokus, laboratorní činnosti, projektovou metodu, kooperativní metody, metody zážitkové pedagogiky) a různé organizační formy výuky, jako jsou terénní cvičení, 
výcvikové kurzy, exkurze, tematické školní výlety, expedice (Hofmann a kol., 2003). Terénní výuku považujeme za jednu z klíčových oblastí prŕípravy pedagogů mimo prostředí fakulty, která má připravovat „kvalifikované“ odborníky vybavené kompetencemi pro výchovněvzdělávací práci s lidmi všech věkových a sociálních skupin v sociálně-pedagogické oblasti prevence a intervence, specifičtěji zaměřené na oblast výchovy ve volném čase“. Různé formy dlouhodobé terénní výuky, kam zařazujeme např́klad i terénní kurzy (viz výše), jsou v úzké návaznosti na teoretickou přípravu. Kromě velké míry kognitivního zaměření rozvíjejí ve velké míře především osobnostní a sociální kompetence budoucího pedagoga. Rozvíjejí rovněž celkově pozitivní vztah k volnočasovým aktivitám a pohybovým činnostem. Jejich zařazení odpovídá záměru a koncepci studia daných oborů.

Terénní výuka napomáhá učitelům a žákům naplnit stanovené vzdělávací cíle, očekávané výstupy i klíčové kompetence jak komplexně, tak v rámci jednotlivých předmětů. Propojuje teoretické poznatky s praktickými, procvičuje a upevňuje vědomosti a dovednosti pro každodenní využití. Ačkoliv terénní výuka je u nás dlouhodobě využívaná jako jedna z forem výuky $\mathrm{v}$ př́rodovědných předmětech, tělesné výchově i předmětech humanitních, nebyla $\mathrm{u}$ nás systematicky a dlouhodobě výzkumně vyšetřována a ani v zahraničí nelze nalézt bohatou nabídku literárních odkazů. Mezi její výhody mimo jiné bezesporu patří výše uvedené praktické využití poznatků, kterým se žáci a studenti naučili ve škole. Dává větší prostor pro skupinovou práci, kooperaci ve výuce, posiluje sociální vztahy, atd. Nevýhodou je pak její časová náročnost na její př́pravu i realizaci. Její dlouhodobé formy jsou náročné i z hlediska finančního. Nezanedbatelná je i finanční náročnost na různé pomůcky do výuky.

Integrovaná výuka je pojem zabývající se propojením obsahu učiva různých předmětů v jeden tematický výukový celek s cílem komplexního poznání využitelného pro praktický život (Podroužek, 2002). Integrovaná výuka (integrované kurikulum) je v současné době jedním ze dvou kurikul, která tvoří edukační proces na základních školách. Tomuto způsobu výuky vyhovuje rozdělení obsahu učiva na základní škole do vzdělávacích oblastí, uvnitř kterých se předpokládá nejjednodušší propojení nebo sjednocení př́buzných tematických celků jednotlivých předmětů. Vzdělávací oblasti ovšem nejsou limitem pro integrovaná témata a styčné plochy lze nalézt i mezi vzdělávacími oblastmi. Již v roce 1958 Dressel objasňuje možnost prolínání předmětových oblastí $\mathrm{v}$ rámci vytvoření nových modelů pro porozumění světa a definuje jejich možná spojení, základy a jednotlivé prvky integrovaného kurikula (Integrated curriculum). Plánované učení prostřednictvím zážitků podle něj poskytne žákům nový širší pohled na obvykle získanou a drženou znalost a také motivuje a rozvíjí žákovy schopnosti povšimnout si nových vztahů, a tak vytvořit nové modely, systémy, a struktury.

Pojem Integrovaná výuka vysvětlují Průcha, Walterová, Mareš (2003) jako výuku realizující mezipředmětové vztahy a spojení teoretických činností s praktickými v následujících formách: 1. integrované předměty nebo kurzy, 2. moduly nebo témata zařazovaná jako součást více předmětů, 3. projekty spojující poznatky z více předmětů s praktickými zkušenostmi a produktivními činnostmi, 4. integrované dny, kdy celá škola realizuje jedno společné téma. Další definici pro Integrovanou výuku nabízí Humphrey, Post, \& Ellis (1981), podle nichž je to způsob vzdělávání, ve kterém děti široce prozkoumávají znalosti různých předmětů příbuzných z určitého pohledu jejich prostředí. Učí se poznávat souvislosti, vztahy, komplexnější pohled na věci, jevy. Peterssen (In Korvas \& Cacek, 2009) definuje Integrovanou výuku (Facherverbindender Unterricht) jako koncentrované, tematicky orientované spojené vyučování, na kterém se rovnoměrně účastní více předmětů. Jednotlivé předměty integrují své příspěvky ve vztahu k centrálním tématům a nadřazenému cíli.

Terénní výuka a integrovaná výuka mají mnoho společného. Nikdy si při její realizaci nevystačíme se znalostmi a dovednostmi jen z jednoho oboru. Má rovněž ještě jeden aspekt, o 
kterém se výše uvedené definice nezmiňují. Práce $v$ terénu s sebou nese nutně i velkou část afektivní stránky výuky a vede k vytváření postojů k místu, kde je provozována.

\subsection{Terénní výuka na PdF MU}

Různé formy terénní výuky patři neodmyslitelně i ke studijním programům na PdF MU. Terénní výuku mají ve svých programech v povinných předmětech katedry geografie, tělesné výchovy, sociální pedagogiky, biologie a v nepovinných predmětech např. $i$ katedra historie. Jednotlivé katedry zajištují terénní výuku na úrovni adaptačních, výcvikových, instruktorských kurzů a nejrůznějších forem terénních cvičení, kurzů a exkurzí. Za více než deset let spolupráce jednotlivých kateder, především katedry tělesné výchovy, katedry geografie a ostatních př́rodovědných kateder a později $i$ katedry sociální pedagogiky, nás přirozeně začaly napadat otázky, jak nejlépe tuto spolupráci zužitkovat a zefektivnit v zájmu zkvalitnění studia a př́pravy studentů na svoje budoucí povolání. Z tohoto hlediska jsme zformulovali i následující výzkumný problém:

Existuji možnosti na PdF MU a následně na základních školách zkvalitnit praktickou připravenost žáků a studentů na život prostřednictvím stávajících forem terénní výuky?

Pro získání odpovědi na výše uvedenou otázku jsme učinili dva kroky:

- Na podzim roku 2010 jsme učinili rozbor různých forem terénní výuky na PdF MU s cílem najít společné prvky terénní výuky. Stalo se tak u terénní výuky katedry geografie, tělesné výchovy a sociální pedagogiky.

- V ř́ijnu 2010 jsme uskutečnili dílčí dotazníkové šetření a strukturovaný rozhovor na padesáti základních školách v ČR.

\section{Výsledky analýzy vybraných forem terénní výuky na PdF}

Analýza probíhala na základě společných zkušeností s pořádáním různých forem terénní výuky na PdF MU. Byly vybrány formy terénní výuky kateder tělesné výchovy, geografie a speciální pedagogiky. Jednalo se o terénní výuku, na které se podílí většinou vyučující ze všech zmíněných kateder. Přesto, že se jedná o jiné cílové zaměření kurzů, mají všechny společné prvky. Využívají do určité míry stejné znalosti, dovednosti i postoje, které jsou charakteristické všem zmíněným oborům. Výsledkem zmíněné analýzy je následující obrázek, který představuje průnik jednotlivých činností do společné stránky terénní výuky.

Rozložení jednotlivých kurzů př́slušných kateder dokumentuje obrázek 1. Celková analýza ukázala obsahový a časový překryv jednotlivých kurzů, logická návaznost aktivit a kurzů existuje pouze na úrovni kateder a nepřehlednost nabídky kurzů pro studenty různých kombinací. Dochází ke zbytečnému časovému a ekonomicky náročnému zdvojování. Analýza ukázala možnost eliminace určitých nevýhod terénní výuky, které jsou naznačeny v úvodu - finanční a materiálová náročnost. Jde zejména o společné využití různých pomůcek, např. GPS a map pro orientaci v terénu, sportovního vybavení v podobě lodí, kol, lan apod. Kurzy se vzájemně doplňují a jejich provázanost je na velké úrovni zejména u učitelství pro 1. stupeň ZŠ. Při vhodném doplnění kurzů o jejich zdravotní aspekty, první pomoc a bezpečnost tak studentům vzniká nová kvalita. Studenti si při takové výuce uvědomí, že není třeba navyšovat terénní výuku na školách. Vyšší kvality mohou dosáhnout logickou provázaností stávajících forem terénní výuky - tedy vytvořením systému terénní výuky. Návaznost mohou na školách zastávat novou funkci v podobě koordinátora terénní výuky a 
volnočasových aktivit. Pracovník, který komplexně chápe metodu terénní výuky a dokáže jí používat, kvalitně zvládá složitou provázanost takové výuky na ZŠ́.

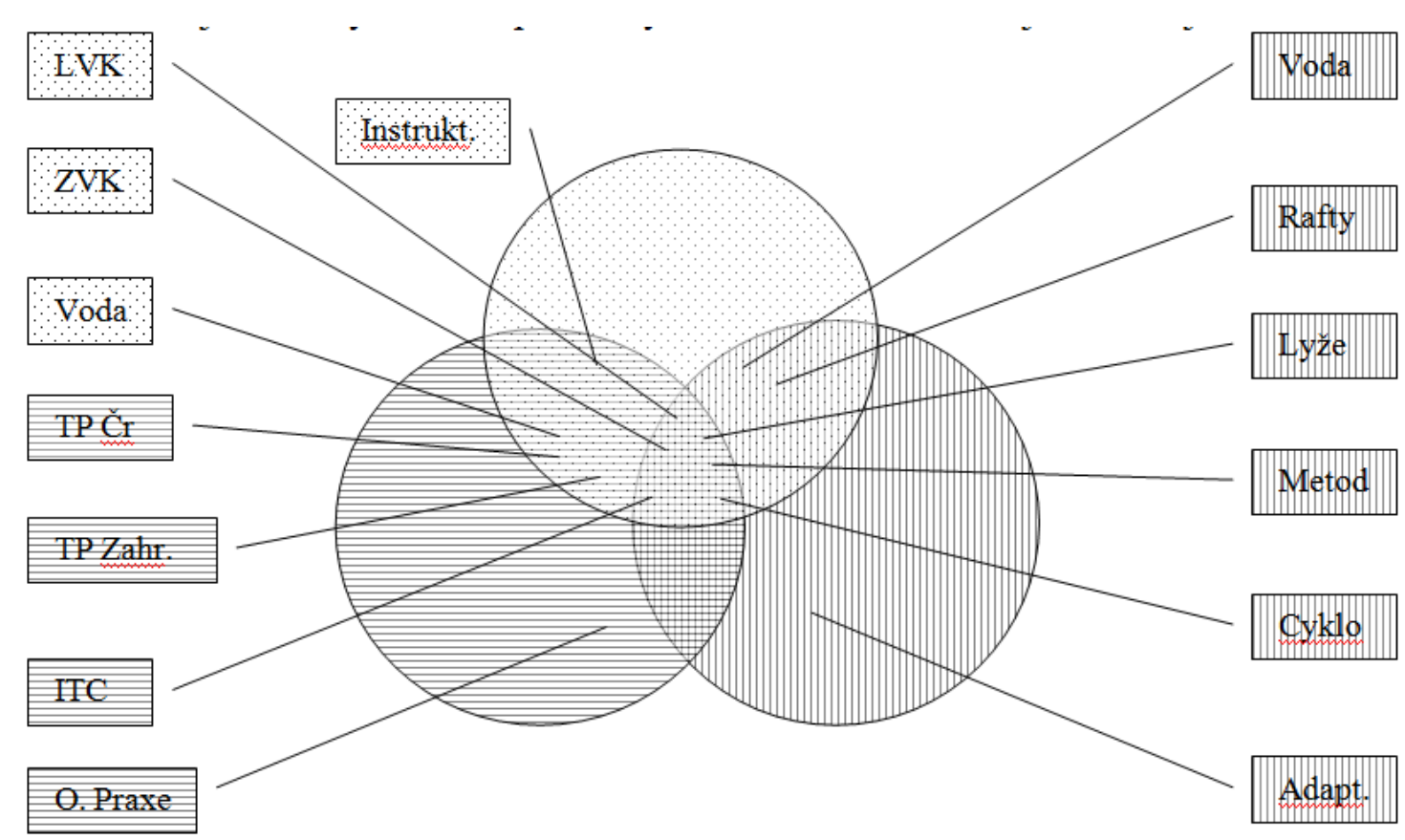

Obrázek 1. Propojení různých forem dlouhodobé terénní výuky na PdF MU.

$\odot$ Rovina pohybové aktivity (pohybové dovednosti, zdravotní benefity, význam pohybu)

$\ominus$ Rovina geografická (charakteristika prostředí, poznávání krajiny, orientace)

(11) Rovina osobnostně - sociálního (zážitková pedagogika, sociální role)

\begin{tabular}{|ll|ll|}
\hline LVK - & letní výcviková kurz & O. praxe - & oborová praxe \\
\hline ZVK - & zimní výcvikový kurz & Rafty - & zahraniční kurz na raftech \\
\hline Voda - & vodácký kurz & Lyže - & lyžařský kurz \\
\hline Instrukt. - & instruktorský lyžařský kurz & Metod. - & metodický kurz \\
\hline TP Čr - & terénní praxe v ČR & Cyklo - & cyklistický kurz \\
\hline TP Zahr - & terénní praxe v zahraničí & Adapt. - & adaptační kurz \\
\hline ITC - & integrovaná terénní praxe & & \\
\hline
\end{tabular}

Zdroj: Autoři, 2011. 


\section{$4 \mathrm{Z}$ výsledků dotazníkového šetření a strukturovaného rozhovoru na vybraných ŽS}

Dotazníkové šetření proběhlo na 50 náhodně vybraných školách v České republice. Jednalo se o základní školy, ze kterých pocházeli studenti, kteří šetření vedli. Bylo provedeno v rámci oborové praxe ze zeměpisu na podzim 2010. Vybrané otázky k řešené problematice byly následující:

- Zjistěte, jek je v jejich ŠVP zařazená terénní výuka, v jakých dotacích a její zaměření.

- Zjistěte, zda má škola systém dlouhodobé terénní výuky na 1. i 2. stupni ZŠ (např. adaptační kurzy, pohybové kurzy, předmětové kurzy, mezipředmětové kurzy, př́ípadně jiné)

- Zjistěte, zda by škola využila učitele, jako koordinátora terénní výuky

- Zjistěte, zda by měli učitelé zájem o další kurzy zaměřené na terénní výuku:

- Kurzy zaměřené na zážitkovou pedagogiku vhodné jako adaptační kurzy

- Kurzy zaměřené na letní a zimní pohybové aktivity

- Kurzy zaměřené na integrovanou terénní výuku

Shrnutí výsledků je následující:

- Terénní výuka na školách probíhá v různých formách, především v krátkodobých.

- Probíhá po předmětech a nemá systematickou propojenost.

- Koordinátora terénní výuky by přivítala polovina dotazovaných škol - tato otázka však nebyla relevantní. Někteří dotázaní si nedovedli představit, co tato funkce znamená.

\section{Závěr}

Závěrem lze konstatovat, že na základě analýzy terénní výuky a z výsledků šetření na vybraných základních školách lze odpovědět na položenou otázku. Zefektivnění terénní výuky na PdF MU lze provést vytvořením centra pro terénní výuku, které bude nabízet její jednotlivé formy všem studentům, kteří o ni projeví zájem. K tomuto účelu bude třeba jednotlivé formy doplnit do přehledných metodických materiálů. Bude nutné specifikovat zaměření a pracovní činnost pro funkci koordinátora terénní výuky a volnočasových aktivit pro základní školu. Předběžně se domníváme, že to bude proškolený odborník pro integraci terénní výuky na ZŠ a náplní jeho práce bude organizační, koordinačni a obsahová garance jednotlivých forem terénní výuky na škole, kde působí.

\section{Literatura}

Hofmann, E. (2009). Reflexe terénni výuky na integrovaném pracovišti PdF MU. In Geografické aspekty středoevropského prostoru. 2. dil. (pp. 37-41). Brno: MU.

Hofmann, E. et al. (2003). Integrované terénni vyučování. Brno: Paido.

Humphrey, A., Post, T., \& Ellis, A. (1981). Interdisciplinary methods: A Thematic approach. Santa Monica: Goodyear Publishing Company.

Korvas, P., \& Cacek, J. (2009). Integrovaná výuka a tělesná výchova na základní škole. Brno: FSpS MU.

Podroužek, L. (2002). Integrovaná výuka na základní škole v teorii a praxi. Plzeň: Fraus. 


\section{Kontakt}

doc. PaedDr. Eduard Hofmann, CSc.

Masarykova univerzita

Pedagogická fakulta, Katedra geografie

Poříčí 7, 60300 Brno

e-mail: evhofmann@ @eznam.cz

Mgr. Petr Soják, PhD.

Masarykova univerzita

Pedagogická fakulta, Katedra sociální pedagogiky

Poříćí 31, 60300 Brno

e-mail: sojak@ped.muni.cz

Mgr. Marek Trávníček

Masarykova univerzita

Pedagogická fakulta, Katedra tělesné výchovy

Poříčí 31, 60300 Brno

e-mail: travnicek@ped.muni.cz

\section{Bibliografické údaje}

Hofmann, E., Trávníček, M., \& Soják, P. (2011). Integrovaná terénní výuka jako systém. In T. Janík, P. Knecht, \& S. Šebestová (Eds.), Smíšený design v pedagogickém výzkumu: Sborník př́spěvků z 19. výročni konference České asociace pedagogického výzkumu (s. 310-315). Brno: Masarykova univerzita.

Dostupné z: http://www.ped.muni.cz/capv2011/sbornikprispevku/hofmanntravniceksojak.pdf doi: 10.5817/PdF.P210-CAPV-2012-11 